\title{
Pulses for Sustainability: Breaking Agriculture and Food Sectors Out of Lock-In
}

\begin{abstract}
Marie-Benoit Magrini ${ }^{1 *}$, Marc Anton ${ }^{2}$, Jean-Michel Chardigny ${ }^{3}$, Gerard Duc ${ }^{4}$, Michel Duru ${ }^{1}$, Marie-Helene Jeuffroy ${ }^{5}$, Jean-Marc Meynard ${ }^{6}$, Valerie Micard ${ }^{7}$ and Stephane Walrand ${ }^{8}$
\end{abstract}

${ }^{1}$ AGIR, Université de Toulouse, INRA, Castanet-Tolosan, France, ${ }^{2}$ BIA, INRA, Nantes, France, ${ }^{3} A L I M H$, INRA, Dijon, France, ${ }^{4}$ Agroécologie, INRA, Dijon, France, ${ }^{5}$ Agonomie, INRA, Grignon, France, ${ }^{6}$ SADAPT, INRA, Paris, France, ${ }^{7}$ IATE, INRA, Montpellier SupAgro, Université Montpellier, CIRAD, Montpellier, France, ${ }^{8}$ UNH, Université de Clermont Auvergne, INRA, CRNH, Clermont-Ferrand, France

Crop diversification can improve the sustainability of Western agriculture. In particular, pulses are crops that can help both agriculture and the food industry become more ecological, as they reduce greenhouse gas emissions and help reduce animal-based consumption. Today, however, the development of these crops in Europe has been hindered due to lock-in, since major crops have been co-developed to a greater extent in farming and food systems. After briefly reviewing the major mechanisms that lead to this lock-in, this article adopts a co-evolution framework to address the interconnected transition of agriculture and food systems. We explore how current societal trends in the agrifood system offer new opportunities for pulses, and how simultaneous changes both in production and consumption can facilitate this dual transition. Drawing on insights from the literature and interviews with stakeholders in France-taken here as examples-we argue that to develop pulses, strong support is required from public institutions to coordinate and guide the multiple actors involved in the same direction.

Keywords: agrifood transition, lock-in, innovation, cropping system, consumer, food behavior, pulses

\section{INTRODUCTION}

Over the last several decades, Western agrifood systems have created externalities affecting the ecosystem and human health (IPES-Food, 2017). These externalities have been caused by the lack of crop diversity and by intensive livestock production systems (e.g., Lang and Barling, 2013; Tilman and Clark, 2014, 2015; Weiner, 2017). These systems were shaped by consumer preferences and path-dependency mechanisms that led to the lock-in of agricultural and food systems (Vanloqueren and Baret, 2009; Meynard et al., 2013). In particular, cereals' increasing returns to adoption marginalized minor crops such as pulses despite their environmental and nutritional benefits (Magrini et al., 2016).

First, for agricultural systems, cereals are the major crops in European farming systems (around $50 \%$ of EU-28 arable cropland), whereas pulses account for around 2\% (Eurostat, 2016). Europe is the top producer of wheat in the world, with France and Germany accounting for almost 50\%. Increasing competitiveness between major species, such as wheat, and minor crops, like pulses, has pushed farmers to exclude the latter from cropping systems (Magrini et al., 2016; Zander et al., 2016). This trend has been also reinforced by scientific research, in which pulses have received less funding than major crops. Sonnino (2017) found that only about $1 \%$ of agricultural research has 
focused on pulses. This strong crop specialization has occurred at the expense of agro-ecological principles such as greater crop diversity and especially nitrogen fixing-plants, which enable a reduction in synthetic inputs (Altieri, 1999; Stoate et al., 2009; Therond et al., 2017; Watson et al., 2017). More broadly, this situation also affects worldwide land use: in 2012, pulse crops occupied $<1$ million square kilometers, whereas cereals, 7 million, and oil crops nearly 3 million (Jahn et al., 2015).

Second, cereals also largely dominate in the food and feed habits of Western countries: in Europe, wheat consumption continues to increase with $45 \%$ of wheat used for feed. In Europe (like in other western countries such as the US), the consumption of animal-protein food is greater than what nutritional guidelines recommend (Ranganathan et al., 2016). For healthier diets, nutritionists advise eating more plant-based proteins, and pulses have the most protein of any plants (Chardigny and Walrand, 2016; Henchion et al., 2017). Pulses also contribute to better health as they reduce diabetes and cholesterolemia (Dahl et al., 2012; Sirtori et al., 2012).

Therefore, pulses could significantly increase the sustainability of our diets (e.g., Ebert, 2014; Jallinoja et al., 2016) as put forward in the FAO's International Year of Pulses in $2016^{1}$. But faced with lock-in, what changes are needed in agricultural and food systems for pulses to develop? To break out of sociotechnical lock-in and move toward more diversified agriculture and consumption of pulse-based foods, radical innovations must occur both downstream and upstream of agrifood supply chains (Voisin et al., 2014; Kuokkanen et al., 2016; Meynard et al., 2016). Such a transition calls for "a dual process that comprises both an upstream and downstream transition. The challenge, therefore, is to understand how these two transitions can be triggered simultaneously in order to coevolve toward a new sustainable agrifood system. A major driver of this transition lies in the greater diversification of plant resources in upstream production systems, which challenges the capacity of the downstream supply chain to promote a greater diversity of plant species in agrofood goods" (Elzen and Barbier, 2012).

Thus, the purpose of this article is to examine whether current pulse innovations in cropping and food systems favor such an alignment between the downstream and the upstream of pulse supply chains. In so doing, we draw on sustainability transition theories that have been developed in the social sciences since the 2000s. These theories highlight the complexity of structural change or "transition" (e.g., Geels, 2004; Foxon, 2011) that result in a coevolution of multiple components of productionconsumption system. This study therefore required adopting an interdisciplinary heuristic framework in order to explain how alignments between technologies, markets, and regulation occur.

The aim of this article is to empower the reader with insights and understanding of the underlying processes that influence pulse development. This collective reflection is based on a review of the scientific and gray literature and analyses of stakeholders' opinions gathered primarily through a set of interviews. These were performed as part of a larger, interdisciplinary research

\footnotetext{
${ }^{1}$ Pulses are defined as the dry seeds of leguminous crops that are not used for oil extraction, such as dried beans, lentils and peas, excluding soy: www.fao.org/ pulses-2016/en/ (Accessed October 30, 2017).
}

project involving French experts who are studying the factors that promote and hinder the development of pulses. This article does not, therefore, report the results of this larger project, but uses them to construct an analysis of the current situation and to suggest some solutions that may help overcome the situation. We adopted a co-evolution framework to consider simultaneously pulses' primary production (here termed upstream) and their processing and consumption (downstream). This enabled us to select the main characteristics of innovation paths on pulses that we found to be fundamental for triggering new actions and breaking out of lock-in. In that sense, this paper is a comprehensive overview of the main challenges facing the future of pulses and as such, also calls for complementary research and actions.

Moreover, while most transition research is based on historical case studies and has thus been conducted ex-post, the originality of this article is in examining the "transition in the making" (Elzen et al., 2011, p. 263): "We call these 'transitions in the making, not because we are able to foresee this will lead to a transition, but because new developments are started... which may (or may not) lead to a transition." Thus, this article enables practitioners to conceptualize the complex and systemic policies needed to escape lock-in.

The focus of this study is to analyze some of the "new developments" in pulses relative to the agrifood sustainability transition. By exploring several innovations both upstream in agricultural systems and downstream in food systems, we examine whether those changes are sufficient to start a transition and then we discuss how policies could reinforced the process. Both our reflections and the stakeholders draw primarily on the case in France. The situation that prevails in that country, which is the top European cereal producer and one of the lowest consumers of pulses, could be more largely applied for Europe.

The first section sets out the theoretical framework for examining the coevolution of agricultural and food systems, identifying current trends that may support the transition toward more pulses. Two areas of innovations are studied: (i) upstream, agronomic practices, primarily fertilization, and valuation of ecosystem services (section Transitions of the Agrifood System: Theoretical Insights and Context); and (ii) downstream, promoting pulses in diets mainly by improving the balance between animal and vegetable proteins through several innovation pathways (section Materials and Objectives). In conclusion, to induce sustainable change, we argue that it is crucial for public agencies to adopt a coevolution view in order to promote simultaneous changes both downstream and upstream of the agrifood system.

\section{TRANSITIONS OF THE AGRIFOOD SYSTEM: THEORETICAL INSIGHTS AND CONTEXT}

Drawing on evolutionary economics, several authors have noted that a coherent organization of agricultural production and food consumption has progressively been woven and lockedin around a technological paradigm based on agro-chemicals 
(Cowan and Gunby, 1996; Wolff and Recke, 2000; Wilson and Tisdell, 2001; Chhetri et al., 2010). This lock-in favors major crops such as wheat and soya (Vanloqueren and Baret, 2008, 2009), marginalizing pulses (Magrini et al., 2016). As a result, today the only way that the agrifood system can break out of this lock-in is if all the inter-connected sectors that shape the agrifood system (such as those which breed seeds, produce fertilizers and pesticides, crop advisory services and harvest collecting, food processing, and retail) change together to favor a more sustainable system such as one with more pulses. The remaining question is how can such a transition in the agrifood system start? To answer that question, we first need to understand the mechanisms that led to lock-in, that is, we need to understand how a technology (i.e., a production method) gradually "dominates" other alternatives by being increasingly adopted (section Lock-In and Increasing Returns to Adoption (IRA) Mechanisms in the Agrifood Sector). Then, we explain the process through which the subsystems shaping the agrifood system co-evolved (section A Co-evolution Approach to Understanding How Agrifood Change Can Occur); within this framework, we need to analyze how current changes in several parts of the system could affect this coevolution. Finally, we suggest how public policy could foster those changes (section Current Societal Trends in the Coevolution of Agricultural and Food Systems).

\section{Lock-In and Increasing Returns to Adoption (IRA) Mechanisms in the Agrifood Sector}

The founding assumption of the IRA theory is that technology is not necessarily chosen initially because it was the best, but it has become the best because it was initially chosen and that choice was reinforced over time. By being chosen first, investments are then concentrated on the first choice, increasing the performance of the dominant technology compared to alternatives that therefore receive less investment. Several contingent factors explain how a first choice occurs, and starting from this first choice, self-reinforcing mechanisms (Arthur, 1989, 1994) make alternatives increasingly difficult to adopt. In the French agrifood system, the historical choice of fertilized cereals and imports of soy from America after World War II resulted in a lock-in situation marginalizing pulses. These mechanisms are analyzed in depth in Magrini et al. (2016), highlighting the role of social interactions and markets. Here, we recall the main IRA mechanisms:

i) Learning by using: a technology's productive performance increases with users' experience.

The learning by doing on cereals and mineral fertilization has led to favoring those practices, all the more so since cereals' yield has greatly improved.

ii) Network externalities: the more adopters there are, the better it is for other users to adopt that technology to take advantage of additional products and services that are developed to be compatible with the dominant technology.
Upstream, this meant the continuous genetic adaptation of wheat to increase the dose of nitrogen fertilization and the development of phytosanitary products for cereals. Downstream, this led to the development of agri-food products based on cereals. Whereas for minor crops, there is no development of phytosanitary products and few market opportunities in the food industry.

iii) Scale economies and economies from learning by doing: the unit cost of production decreases over time as a result of volume and improved technology, making the technology even more attractive.

Upstream, since R\&D both for breeding and phytosanitary products (registration, distribution) is generally plant-specific, investments have been made with the goal of producing substantial production volumes to make that investment profitable. On the farm side, the process of specialization is explained by the greater ease of acquiring technical control, the amortization of agricultural equipment, and the organization of work with some crops in which the farmer specializes. The adoption of major crops has thus been reinforced to the detriment of other species such as pulses, whose yields are lower and/or more variable, in particular because technical advice and varietal selection are less advanced. Downstream, organizations for storage, processing, and selling the crops follow the same rationale: specializing the business in a few dominant species led to economies of scale, thereby reducing the marginal cost of use for a given species.

iv) Informational increasing returns: the more a technology is used, the more it is known and understood, thereby encouraging other users to adopt it.

Upstream, this means more advice favoring mineral fertilization and cereal cultivation (by public and private technical institutes, cooperatives, the trade press, etc.), with little advice focused on managing the nitrogen supply ecosystem service of legumes. Downstream, the increased consumption of cereal-based products has led to increased knowledge on the technical-functional properties of cereals within the agrifood industry.

v) Technological interrelatedness: other technologies and production standards are established in line with the dominant technology.

The industrialization of agri-food chains has led to a growing number of production standards that contribute to locking practices. For example, requiring high level processing qualities (protein rates for both bakery and pasta) hinders the adoption of innovative farming systems that use less nitrogen fertilizers.

Thus, it is clear why IRA are termed "increasing": the greater the number of users, the greater the value for these users at the expense of alternatives. Therefore, even though today it is widely recognized that greater crop diversity would provide a broader range of ecological services through their functional properties and would therefore enable a significant reduction in synthetic inputs (e.g., Therond et al., 2017), it is hard to break out of the path chosen previously, that led to crop specialization, 
a considerable use of chemicals, and greater environmental problems.

\section{A Co-evolution Approach to Understanding How Agrifood Change Can Occur}

The sustainability transition literature starts with this finding: the systems fulfilling societal functions such as food supply are locked-in. To highlight how change could occur, this literature argues for the coevolution in several areas such as social, political, economic, and technical ones (Elzen et al., 2011). This body of work highlighting the complexity of transition provides a new analytical perspective "particularly relevant for addressing environmental and sustainability challenges" (Foxon et al., 2013, p. 190). While the energy and transportation sectors have been largely analyzed with this framework, little work has been done on agrifood systems (Markard et al., 2012; Touzard et al., 2015). Several authors stress the need to consider agriculture and food as closely linked, yet few studies explicitly tackle the joint transition of agriculture and food systems (Francis et al., 2003; Marsden, 2012; Kuokkanen et al., 2016; Meynard et al., 2016).

Indeed, analyzing the entire agrifood system and the interactions between its components is very complex. One way to tackle this transition is to consider it as a dual process comprising both an upstream and a downstream transition. Then, the "transition of the agrifood system" can be viewed as a dual transition implying simultaneous changes in both agriculture and food systems. For the present analysis, we drew on Foxon's framework (2011) that identifies complex interactions between five main components (Figure 1):

- Institutions (I) denote the set of social rules (North, 2003). The institutional environment refers to all collective rules of action (political, social, legal), such as agricultural trade agreements, environmental protection policies, and standards such as food consumer standards (Allaire, 2010). These rules are conveyed through explicit as well as tacit norms. Institutional arrangements refer to that ways that agents organize economic transactions within these rules (Laperche, 2012).

- Technologies (T) refer to technological processes and practices of a given type of production used by firms, including scientific knowledge.

- Business activity (B) of firms means the economic strategy for producing goods and services that meet the expectations of users (U) in accordance with the other system components.

- All these choices interact with or affect ecosystems (E), understood as the ensemble of all natural resources (water, air, soil, biodiversity, etc.), which themselves influence firms' production capacity, particularly as regards food products.

The interactions among those sub-systems are too numerous to be explained in detail here. However, we should note that the environment influences technical choices as well as the choices of businesses and users, and is increasingly taken into account by institutions regulating stakeholders' actions (Rennings, 2000). Aligning changes between these sub-systems is necessary to break out of lock-in.

As we consider these two systems in a dual transition, we expanded Foxon's diagram (Figure 2) to include the upstream and downstream of the agrifood system through the supply chain. Thus, our approach is similar to Kuokkanen et al. (2016), who divide the food system transition into three co-evolving dimensions: production, institution, and supply chains. Cropping systems are combinations of agricultural practices depending of several inputs processors (seeds, phytosanitary products), including crop rotation, variety, soil tillage, fertilization, crop protection, irrigation for arable crops; whereas the processing of harvested crops are defined by other technical processes. They are strongly connected: for example, grain qualities must be adapted to food processing requirements (Meynard et al., 2016). In another example, new consumer preferences may lead the upstream of the supply chain to change cropping systems that will have in turn affects on ecosystems, or more precisely here agroecosystems.

Thus, the challenge is to understand how changes can be triggered simultaneously in order to coevolve toward a new sustainable agrifood system. We detail below the main current trends paving the way for a transition to diversified cropping systems with pulses as well as food uses for those crops.

\section{Current Societal Trends in the Coevolution of Agricultural and Food Systems}

To increase interest for pulses both upstream and downstream, the agrifood transition could be linked with other major transitions (Figure 3):

- The energy transition: the long-term depletion of fossil-fuel resources affects the production of mineral fertilizers. The increase in prices of inputs may reduce the gap in profit margins between protein-rich pulses and cereals in the coming years, as high European yields for cereals depend strongly on the use of large amounts of fertilizer (Magrini et al., 2016). Yet up to now, the increasing price of cereals has limited this trade-off opportunity ${ }^{2}$ (Loyce et al., 2012).

- The ecological transition is related to the energy transition. It refers to the challenge to develop natural-resource-based systems to reduce the negative externalities from syntheticinput-based ones (Garnett, 2013). For agriculture, this agroecological transition (Horlings and Marsden, 2011; Therond et al., 2017) aims at reducing the use of chemicals to preserve biodiversity and public health. One challenge is to reduce the use of mineral fertilizers whose production, transport, and use significantly contribute to greenhouse gas emissions (Lassaletta et al., 2014), which in turn drive climate change. This challenge calls for increased use of pulses in cropping systems, as they do not need nitrogen

\footnotetext{
${ }^{2}$ Loyce et al. (2012) have shown that with lower global wheat prices in 1990s and early 2000s, low-input crop management for lower $\mathrm{N}$ input systems were more profitable. But in the context of very high wheat prices (as at the end of the 2000s) "high-input systems making use of high-yielding cultivars are currently more profitable" (p. 174). The authors concluded that the tradeoff between profitability and environmental benefits is very sensitive to grain and oil prices. There is less dependence on oil prices, however, because, according to the authors' calculations, the elasticity between the price of nitrogen fertilizer and oil is 0.55 (i.e., an increase of $55 \%$ in $\mathrm{N}$ fertilizer costs for a $100 \%$ increase in fuel costs, p. 170). Thus, although production with intensive synthetic inputs has clear energy and environmental disadvantages, the profitability of this high-input system depends mainly on a high wheat grain price.
} 


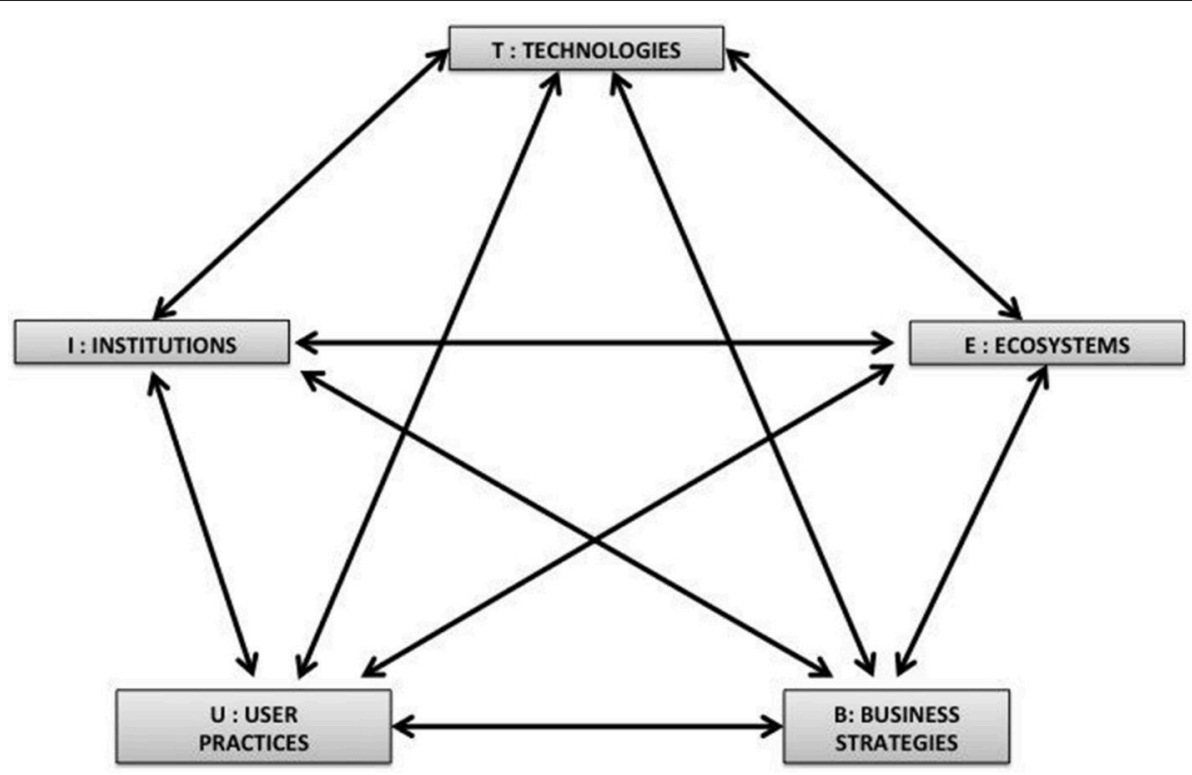

FIGURE 1 | Coevolutionary framework (Foxon, 2011).

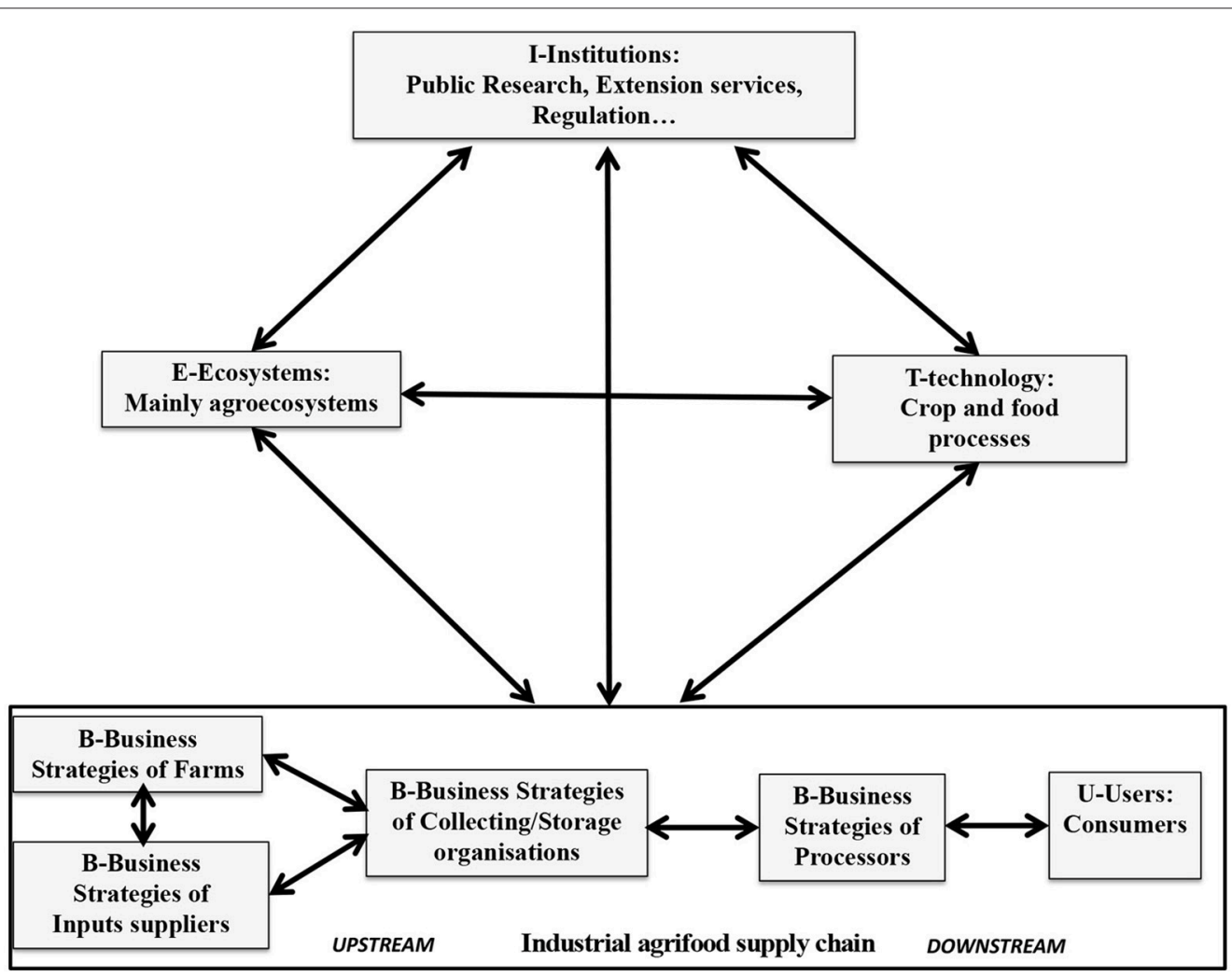

FIGURE 2 | A coevolutionary framework for conceptualizing the transition of the agrifood system.

fertilizers and also reduce the fertilizer requirements of the following crop (Nemecek et al., 2015). Greater crop diversity in cereal-based cropping systems also helps reduce pesticide use (Weiner, 2017). Crop diversity and legumes also affect soil fertility (Gogoi et al., 2018). Finally, as nearly half of cereal production is used for animal feed, less animal-based, and 
more pulse-based diets have lower greenhouse gas emissions and land use (Friel et al., 2009; Scarborough et al., 2014; Hallström et al., 2015; de Boer and Aiking, 2018).

- The demographic transition: The world's growing population (from 7 billion today to over 9 billion people in 2050) will increase food demand (by 50\% from 2013-2050, FAO estimates). The lack of additional arable land and increasing farming productivity and yields are needed to meet food security objectives. But this increase in yields must be done without expanding the agricultural frontier at the expenses of natural resources, and be tackled differently according to the yield gaps observed around the world. For the most intensive cropping systems, "upper yield plateaus" have been observed (Grassini et al., 2013; Tilman and Clark, 2015) for wheat in northwest Europe and maize in southern Europe. This is partly due to shorter crop rotations in agriculture, meaning major crops are more frequently cultivated on the same land thereby reducing some positive agronomic services that could otherwise be provided by crop diversification (Benett et al., 2012; Weiner, 2017). Crop diversification with legumes is thus advanced as a more comprehensive approach to lowering yield variability and improving the resilience of cropping systems, especially for lowering the inputs needed (Bedoussac et al., 2015; Cernay et al., 2018). While increasing yields remains essential in some parts in the world, and given that the global transition calls for fewer synthetic inputs, other solutions are needed to reach food security. One such solution would be greater direct consumption of plant-based foods, thereby reducing land needs for feed, which could be allocated to producing more plant-based food (Nijdam et al., 2012; Garnett, 2013; Westhoek et al., 2014; Henchion et al., 2017).

- The epidemiological transition: reducing infectious diseases has given way to an increase in non-communicable diseases (termed chronic or diseases of modern civilization) such as obesity and cardiovascular disease: "Research anticipates that global rates of diet-related diseases will continue to increase as diets shift toward increased calorie, empty calorie, and meat consumption" (Tilman and Clark, 2015, p. 16). This raises the question of changing eating habits (Auestad and Fulgoni, 2015) to favor healthier foods such as pulses (Curran, 2012; Dahl et al., 2012; Mudryj et al., 2014; Havemeier et al., 2017).

- The previous two transitions are related to the nutritional transition: Western diets over the past century have increased consumption of animal products. Yet plant-protein diets provide a cheaper protein supply and require less energy to produce. In addition, of all protein-rich plants, legumes are the ones whose nutrition profile best complements that of cereals (Chardigny and Walrand, 2016). Finally, as consumers are also increasingly concerned about ethics and animal well-being, these aspects may signal a major dietary change in the years to come (Clonan et al., 2015; de Boer and Aiking, 2018).

Pulses can help address some of the issues raised by these transitions. What are the current innovation paths of pulses? Have any changes already begun on the components of the system, and are they sufficient to promote the development of pulses both upstream and downstream of these systems?

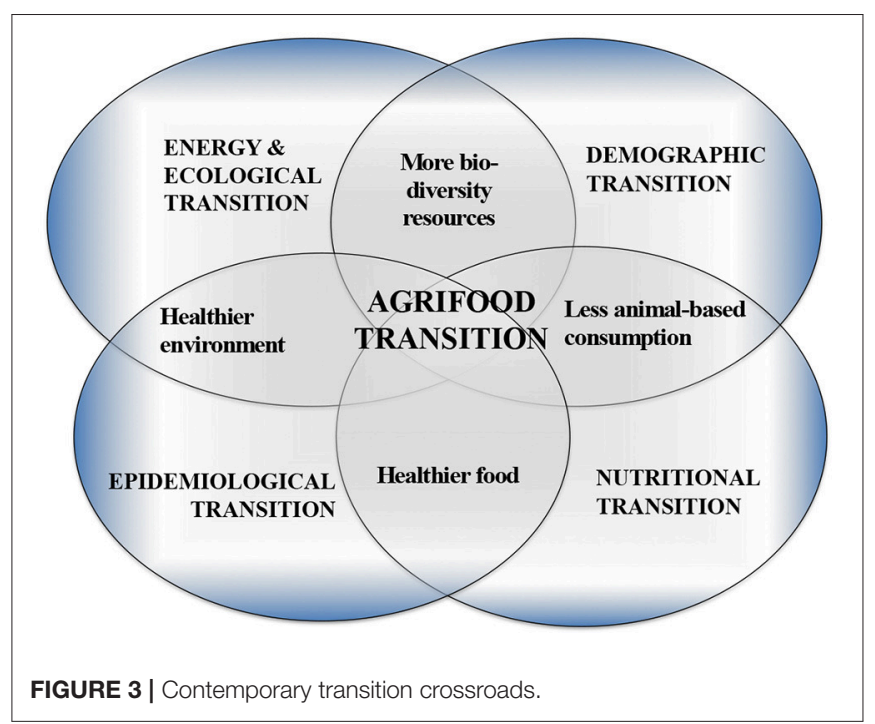

\section{MATERIALS AND OBJECTIVES}

Our objective here is to map and to analyze several main innovation paths that are currently shaping the pulse sector. We draw on various sources in order to form a comprehensive and synthetic analysis of the main issues in pulse development, with particular focus on the French sector as an example. This analysis is based on:

- Research on pulses;

- Open-ended interviews among representative stakeholders of the French agrifood sector, such as agricultural cooperatives, food processing firms, and retailers. Table 1 details the various types of organizations that were interviewed over the three last years as part of several other studies, amounting to around 50 interviews. Most of these interviews were conducted for specific research on one topic in the development of pulses. The objective here is not to present the detailed methodology and results from these interviews, but rather to sum-up their main insights (for more details, see the relevant publications. The generic open-ended guidelines for these interviews are given in the Appendix).

- Technical and economic reports from French research institutes such as INRA (the French National Institute of Agricultural Research), ANSES (French Agency for Food, Environmental and Occupational Health \& Safety), agricultural extension services, industry organizations, and the Ministries of Agriculture and Food;

- Other discussions were also conducted during specific professional meetings (several authors of this paper also serve as experts for the institutions mentioned), and academic seminars and conferences. These formal and informal exchanges between researchers and stakeholders enabled us to better define the main issues. In particular, we also drew on information from several workshops organized at the end of 2016 on various pulse development topics. Those workshops 
TABLE 1 | Main types of information provided by different stakeholders.

\begin{tabular}{|c|c|c|c|}
\hline Category & $\begin{array}{l}\text { Type of } \\
\text { organization }\end{array}$ & Name & $\begin{array}{l}\text { Open-ended interviews/discussions } \\
\text { conducted between } 2013 \text { and } 2016\end{array}$ \\
\hline Institution & Public Agency & $\begin{array}{l}\text { ANSES (French Agency for Food, Environmental, and } \\
\text { Occupational Health \& Safety) }\end{array}$ & Regular discussions 3 to 4 per year \\
\hline Institution & $\begin{array}{l}\text { Agricultural } \\
\text { extension services }\end{array}$ & $\begin{array}{l}\text { Terres Inovia (Unip before 2015) } \\
\text { Agence Bio (the French organic agriculture agency) } \\
\text { CER (Accounting agency for farmers) }\end{array}$ & Regular discussions 3 to 4 per year \\
\hline Institution & Association & French Vegetarian Association & 1 open-ended interview \\
\hline Upstream firm & Farms & $\begin{array}{l}\text { Open-ended interviews of } 143 \text { farms in France from three } \\
\text { regions (north, west, and south) }\end{array}$ & $\begin{array}{l}\text { A study on obstacles and drivers for } \\
\text { cultivating pulses in } 2015 \text { (more details in } \\
\text { Nguyen et al., 2016) }\end{array}$ \\
\hline $\begin{array}{l}\text { Downstream } \\
\text { Firm }\end{array}$ & Agrifood firms & $\begin{array}{l}\text { Soufflet, Roquette, Sabarot, Panzani, Barilla, Tipiak, Nutrion } \\
\text { and Santé, Nutrinat }\end{array}$ & $\begin{array}{l}1 \text { to } 2 \text { open-ended interviews with each } \\
\text { firm }\end{array}$ \\
\hline $\begin{array}{l}\text { Downstream } \\
\text { Firm }\end{array}$ & $\begin{array}{l}\text { Catering food } \\
\text { suppliers }\end{array}$ & $\begin{array}{l}\text { Sodexo (international company), Récapé (French small-sized } \\
\text { company in southern France) }\end{array}$ & 2 open-ended interviews \\
\hline $\begin{array}{l}\text { Seminar, } \\
\text { Congress }\end{array}$ & Title & Organized by & Place, date, number of participants \\
\hline French Seminar & $\begin{array}{l}\text { Pulses in food } \\
\text { ("Les } \\
\text { légumineuses à } \\
\text { graines en } \\
\text { alimentation } \\
\text { humaine") }\end{array}$ & $\begin{array}{l}\text { INRA } \\
\text { https://www6.inra.fr/groupes-filieres/Filieres-Vegetales/ } \\
\text { Filiere-Legumineuses/Actualites-Evenements-du-groupe/ } \\
\text { Evenements-passes/Rencontres-2014/Seminaire- } \\
\text { Legumineuses-a-graine-en-alimentation-humaine }\end{array}$ & Paris, France, October 2014, 130 \\
\hline $\begin{array}{l}\text { French } \\
\text { workshops }\end{array}$ & COSELAG Project & $\begin{array}{l}\text { INRA (Research Institute), Terres Univia, Terres Inovia } \\
\text { (Professional Organizations) } \\
\text { http://www6.inra.fr/coselag/ }\end{array}$ & Paris, France, November 2016, 120 \\
\hline
\end{tabular}

were part of a French project, $\mathrm{COSELAG}^{3}$, designed to obtain collective expertise on legumes from stakeholders and scientists in different disciplines. The results of this project are available on COSELAG's website.

Hence, the objective of this paper is not to review in detail the information gathered, but to present our collective analysis of the issues based on the findings from these various sources. Drawing

${ }^{3}$ COSELAG is a French project that aims to identify the major changes that may influence the strategy of pulse breeding. Several workshops have been organized on various subjects such as: the evolution of cropping systems with pulses, the evolution of institutional frameworks on pulses, consumer preferences, and new technologies. A synthesis of each topic is available on the website: http://www6. inra.fr/coselag/ on recent advances in the literature on legumes and feedback from stakeholders, in the following sections we identify some of main characteristics of innovation paths on pulses. We selected those that appeared most fundamental from breaking out of lock-in, that is, the ones liable to trigger IRA mechanisms in favor of pulses both downstream and upstream of the agrifood system.

\section{UPSTREAM CHANGES TO DEVELOP PULSES IN CROPPING SYSTEMS}

The emphasis on ecosystem services, especially nitrogen management, is the strongest trend currently driving the 
interest in pulses in cropping systems for most actors. Farmers, cooperatives, and breeders have shown little interest in legume crops up until now, and so dissemination of knowledge is the first step needed for un-locking the system (section New Knowledge from Research Institutions on Cropping Systems). However, firmly establishing these greener practices requires multiple changes: in farming practices (section Farming Practices and Technical Advice from Agricultural Institutions), in breeding and supply chains (section Breeding, Innovative Agronomic Practices, and Supply Chain Consequences), and through multiple interactions among all actors to consolidate and disseminate that knowledge, with institutions playing a key role (section Feedback Insights: The Main Role of Institutions).

\section{New Knowledge From Research Institutions on Cropping Systems}

As defined by the Millennium Ecosystem Assessment, three types of services are provided by the symbiotic fixation of atmospheric nitrogen, which is a specificity of pulses (Reckling et al., 2016): (1) provisioning (fixing atmospheric $\mathrm{N}_{2}$ helps produce protein-rich foods); (2) supporting (fixed nitrogen helps to improve soil fertility for subsequent crops and fertilization of the following crops may be significantly reduced); and (3) regulating (symbiotic fixation reduces the use of chemical fertilizers and thereby reduces the negative impacts linked with their use such as greenhouse gas emissions and fossil fuel consumption). Legumebased crop diversification also reduces pesticide use (primarily herbicides, Wezel et al., 2014) and increases the diversity of landscape mosaics, promoting biological regulations that further reduce the need for pesticide use (Vasseur et al., 2013).

These significant environmental benefits of pulses are increasingly promoted by French public research institutions, the government, and technical institutes. A free handbook on pulses published by the French government, the French technical institute Terres Inovia, and the national research institute INRA is one main example (Schneider and Huyghe, 2015). This book for researchers and practitioners synthesizes the benefits of pulses at the scale of cropping systems and at the scale of national production systems, similar to other international syntheses such as Jensen et al. (2012) and Murphy-Bokern et al. (2017). This important push to disseminate knowledge was created to try to change the fact that, in practice, these services are currently poorly valued by farmers and agricultural advisers. Generally, they are unfamiliar with the benefits of crop diversification (Meynard et al., 2013; Reckling et al., 2016). In organic systems, pulses are more frequently grown, but far less so in conventional systems (Zimmer et al., 2016).

\section{Farming Practices and Technical Advice From Agricultural Institutions}

Conventional farmers (within the agro-chemical paradigm) rarely take into account the medium-term, biology-based effects of minor crops in their rotations (Magrini et al., 2016). Our openended interviews with technical advisers of storage organizations confirm indeed that the introduction of pulses into a crop sequence is rarely linked to adapting the nitrogen management of the following crops, although the nitrogen supply from pulses can result in decreasing $\mathrm{N}$ fertilizer from 20 to $80 \mathrm{~kg} \mathrm{~N} / \mathrm{ha}$ (more details reported in Anglade et al., 2015; Schneider and Huyghe, 2015). This variability hinders farmers when precisely adapting fertilizer doses, as current methods estimate the $\mathrm{N}$ supply needed from the preceding crop. New knowledge or indicators on this variability are required to more accurately value this legume-based service. Fertilizing based on regularly measuring the nitrogen nutrition status of the following crop should help us to better value the preceding effect of legume crops (Ravier et al., 2018). Yet up to now, farmers find it easier and more reliable to base the nitrogen nutrition of their crops on synthetic fertilizers than on biological soil processes because they lack such information. The decision tools available to them have also been designed within the synthetic-fertilizer paradigm.

Thus, improving the environmental and economic assessment of introducing pulses at the scale of the cropping system presupposes a deep understanding of that system: farmers must switch their practices from the agro-chemical input-based model to a more biological-regulated model that requires more local observation and local know-how (Toffolini et al., 2016). This is a great transformation that demands new skills among farmers and new information support from advisory services, such as accounting systems to calculate the multi-year effects of practices. In several case studies, multi-year assessment of introducing pulses in cropping systems showed no economic loss or gain, thanks to the cost reduction that pulses enabled on other crops (Schneider and Huyghe, 2015; Ravier et al., 2018). However, from interviews with accounting agencies, we found that few farmers use a multi-year evaluation of crop margins, as they are encouraged to use the year-based tools provided by the accounting agencies that are advising farmers. Annual crop-based margins do not reveal the economic advantages of pulses.

Taking into account the multi-year effect of pulses requires greater support from agronomic advisers from both public and private institutions. Agricultural extension services are currently not able to advise on choosing the legume species best adapted to local environmental factors and its place in the rotation. In fact, a wide variety of legume species can be grown in Europe (winter or spring peas, winter or spring fava beans, white or blue lupins, soybeans, lentils, dry beans, chickpeas, etc.) with several possible management patterns (pure crops or intercrops). Yet there is currently no management tool to help farmers choose the most suitable pulse crop to grow according to the targeted services it may provide and its local adaption to soil and climate conditions. The majority of scientific and technical reference data available in Europe is limited to peas, the most cultivated pulse species. The potential for growing and using a wide range of legume species deserves to be better evaluated. In particular, all actors agree that research is urgently required for quantifying the yield performance and the preceding-crop effects of various legume species grown in diverse soil and climate conditions. This is needed in order to increase the reference data available and at the same time to foster crop biodiversity.

\section{Breeding, Innovative Agronomic Practices, and Supply Chain Consequences}

Creating new varieties is another major means advanced by stakeholders for securing yields. We need to increase their 
adaptation to a given environment and select traits favoring resistance to biotic and abiotic stresses and their adaptation to a diversity of cropping systems. Even though large genetic resource collections are available throughout the world, and new genomic tools are making rapid progress in speeding up the selection process, the small size, and the low number of breeding programs in private and public European organizations still hinder genetic progress on these species. Indeed, in 2015, fewer than 400 new pea varieties were publically registered in Europe, and fewer than 150 for beans, while there were nearly 2,500 for wheat (Magrini et al., 2016).

To characterize and quantify the performance and ecosystem services of pulses, today public research institutes and agricultural cooperatives are experimenting with innovative cropping systems such as legumes-cereals intercrops (for instance wheat/pea, durum wheat/fava-bean, and triticale/lupin), primarily grown in organic systems. By growing species together in the same field, intercrops provide ecological functions that increase resource-use efficiency compared to species grown in pure stands. It also leads to greater yields than the average of both pure crops (Pelzer et al., 2012; Bedoussac et al., 2015). Legumebased intercropping enables higher nitrogen use efficiency and far lower fertilizer use compared to pure crops. In addition, intercropping reduces the risk of nitrogen leaching into the environment and is an effective way to reduce air-borne diseases, weeds and sometimes pests, and all of which enable a reduction in pesticide use (Ndzana et al., 2014). Finally, intercropping also improves product quality, such as the protein content in cereals, up to 2 points more in low-input systems (Bedoussac et al., 2015). This agronomic innovation opens up new outlets for wheat (both for pasta and bread), especially for organic markets. Considering the great diversity of intercrops possible, more research is still needed to design support tools that help farmers choose the best species to intercrop depending on the results desired and the pedo-climatic conditions (Anglade et al., 2015; Kuhlman et al., 2017).

Yet the practice of intercropping is also limited because logistics are not adapted for pulse sorting by harvesting/storage firms and market organizations (Magrini et al., 2013). However, several cooperatives in France, such as Terrena (one of the major French cooperatives) and Qualisol (a small-sized French cooperative), have recently adapted their logistics and organized their advisory services to promote intercropping. In addition, these cooperatives have created new value food chains for lentils (Qualisol) and lupins (Terrena) to reach higher value markets. Qualisol even created its own brand and adapted its packaging and market outlets. Qualisol sells lentils directly to consumers and to food ingredient suppliers in long supply chains. In order to sell "pure" lentils or "pure" wheat harvested from intercrops, they invested in a highly efficient optical sorter. They also set up an advisory organization to introduce farmers to intercropping. This example shows how several innovations were simultaneously designed (technical, organizational, and marketing) that enabled the increased use of pulses in cropping systems. More research should focus on designing this type of interconnected-innovation and specifically, its collective organization since it generally involves several actors (Meynard et al., 2016).

\section{Feedback Insights: The Main Role of Institutions}

Agricultural institutions, especially for research, advising, and education, have a key role to play in the collective education needed for transitioning to farming systems with more pulses. Education and disseminating knowledge are key factors for the transition (Kemp et al., 1998). This progress will be fostered if the agricultural system supports the development of knowledge and innovative practices: (i) it should include more programs on pulses during initial agricultural training for young farmers; and (ii) more advice and technical reference data for farmers. Hence, increasing legume crops requires mobilizing these organizations and thus requires new training for their employees.

According to our open-ended interviews, French ministries also acknowledge that European public subsidies are not enough. They recognize that the greening measures of the new Common Agricultural Policy (CAP), which began to be implemented in 2015 and introduced the green direct payment scheme, are not sufficient to significantly increase these crops. Other experts interviewed in Mahmood et al. (2017) had similar findings: as prices on pulses are not high enough compared with major crops like wheat, more price incentives are needed for French farmers to grow them.

Most of the stakeholders interviewed felt that new outlets with a higher added value are needed to create economic incentives for cultivating these species. Interviews with the top twenty French cooperatives (Cholez et al., 2017) reveal that they consider the market value of pulses too low to be included as a main part of their business strategy, except for a few market niches such as peas or lupins for food ingredients. This competitiveness problem also derives from the fact that the environmental services provided by those crops are not valued by the market. Yet smaller cooperatives' strategies (Qualisol, cited above) show that niche-markets may also be created for pulse consumption.

\section{DOWNSTREAM CHANGES TO PROMOTE PULSES IN HUMAN DIETS}

As the agro-ecological benefits of pulses are increasingly promoted, information about their contribution to more sustainable diets is also increasing (section Advances in PlantBased Protein Research for Food). But while new scientific knowledge and breakthrough innovations in the agrifood industry provide new market opportunities, the future of these innovations is also strongly linked to institutional changes in nutritional classifications and consumer preferences (section Institutions: Pulses for Human Diets), knowing that consumer preferences are highly dependent on nutritional and culinary education (section Nutritional and Culinary Education of Consumers About Pulses). In addition, we observed recent technological progress enabling more innovative food products (section Food Processing Innovations: New PulseBased Products) especially concerning proteins (section Food Processing: The Development of Protein Ingredients), but currently this still needs stronger connections with the upstream 
of the supply chain (Coupling Upstream and Downstream Innovations).

\section{Advances in Plant-Based Protein Research for Food}

Human diets in most developed countries have too many calories from animal sources (Combris et al., 2011; Garnett, 2013; Whitmee et al., 2015). Currently, developing countries (China, Brasil, India, etc.) are following the same path with a large increase in animal-based food consumption. As a result, micronutrients, fiber, and polyunsaturated fatty acid intake are unbalanced and more attention needs to be paid to assessing the nutritional balance between animal and plant foods. Moreover, as mentioned in Section Transitions of the Agrifood System: Theoretical Insights and Context, the environmental considerations of dietary choices are a growing concern (IPESFood, 2017). Most of the people interviewed stated that protein delivery in terms of energy use and GHGs (including production and transport) is more efficient for pulses than animal proteins or other plant proteins, which has also been demonstrated in the literature (e.g., González et al., 2011). The environmental footprint of pulses is thus far lower than animal protein sources (Nijdam et al., 2012; Marlow et al., 2015). Therefore, promoting the nutritional properties of pulses can lead to higher consumption of pulse proteins as partial substitution for animal proteins. In addition, with the predicted increase in meat prices and global population growth (OECD-FAO, 2013), households seeking to reduce their food costs may begin to include more pulses in their diets.

However, animal proteins are known to offer the best nutritional quality protein and are better assimilated by the human body, which is essential when meeting infant developmental needs and for maintaining body protein mass in the elderly (Tome, 2012). Strong progress has been made in understanding the nutritional efficiency of pulses by specific combinations of plant protein sources to ensure the complementarity of essential amino acids needed for protein metabolism and repair. Recent studies show that the simultaneous consumption of proteins from pulses and cereals reproduces the pattern of essential amino acids contained in animal products (Petitot et al., 2009, 2010; Chardigny and Walrand, 2016; Laleg et al., 2016, 2017).

\section{Institutions: Pulses for Human Diets}

Although there has been considerable progress in research, new food applications are scarce. In France, firms state that they do not promote the nutritional benefits of pulses to consumers because public institutions do not classify pulses as an animal protein alternative. Indeed, French agencies, such as National Advisory on Food (Conseil National de l'Alimentation) do not publicly promote balancing the intake of proteins from animal and plant sources, despite the fact that the scientific public recommendation is a $50 / 50$ balance. Pulses are classified as starches alongside cereals in the French food pyramid, but more consumers increasingly cite pulses as a protein source: in 2016, 31\% of French consumers considered legumes as rich-protein sources compared with $11 \%$ in 2011 based on a representative consumer survey (GEPV, 2016).

Yet French national standards from the GEM-RCN (national group of company representatives that promote nutritional recommendations for the restaurant/catering industry) limit the frequency of consumption of vegetable protein dishes from four to twenty successive meals. However, in other Western countries, food pyramids classify pulses as a source of protein and a meat alternative ${ }^{4}$ for example, the top of the USDA's dietary recommendations reads, "With protein foods, variety is key. Protein foods include both animal (meat, poultry, seafood, and eggs) and plant (beans, peas, soy products, nuts, and seeds) sources." Since the first food guidelines were introduced in Canada in the 1940s, pulses have been presented there as alternatives to animal proteins. This policy, combined with issues of crop diversification, means that for several decades Canada has had a strong policy promoting pulses as food. Today, pulse consumption in Canada is the highest among Western countries at around $10 \mathrm{kilos} /$ person/year, whereas the average in other Western countries is around 4 kilos and $<2$ in France (FAOStats). Several European countries classify pulses as a protein source, such as the United Kingdom, Spain, Italy and more recently Belgium, which adopted this classification in 2017. Many firms interviewed believe that a strong public awareness campaign on the nutritional properties of pulses is one of the main programs needed to change consumer behavior. In France, there have been discussions on this subject between the research institutes INRA and ANSES (French Agency for Food, Environmental and Occupational Health \& Safety), which led to a significant change in the institutional position: in January 2017, ANSES updated its food consumption guidelines with a specific recommendation to increase pulse consumption and reduce meat consumption. Yet French institutions continue to classify pulses as carbohydrates.

Advances in scientific knowledge on these species have also revealed other nutritional benefits. In a recent survey, Champ et al. (2015) reported that pulse consumption had preventive effects in some non-communicable diseases (type 2 diabetes, mellitus, dyslipidemia such as hypercholesterolemia, colon cancer, etc.). However, for European authorities to approve specific nutritional claims, additional research for "evidencebased" statements are required, while in non-European countries (like Canada) such claims have already been accepted. For example, in Canada, pulses are recognized as being rich in fiber (Curran, 2012), while this claim is rarely on French product packaging. Several ongoing studies are also trying to better assess the effects of pulses in terms of fiber intake and micronutrients such as potassium, in order to correct nutritional deficiencies of certain age groups. For example, the diets of elderly people are often characterized by a sharp reduction in meat consumption, partly due to problems chewing as well as

\footnotetext{
${ }^{4}$ http://www.choosemyplate.gov, the official site of the USDA, Center for Nutrition Policy and Promotion, is the equivalent of the French PNNS. See also the food pyramid recommended by the Harvard School of Medicine in the US: https:// www.hsph.harvard.edu/nutritionsource/healthy-eating-plate. For the Canadian government's food guide, in which "cooked pulses" are listed as an alternative to meat products, see http://www.hc-sc.gc.ca/fn-an/alt_formats/hpfb-dgpsa/pdf/ food-guide-aliment/view_eatwell_vue_bienmang-eng.pdf.
} 
budget considerations. This results in a deficiency for people who in fact have increased protein requirements as they age. Several firms interviewed are developing research on new foods, such as bread or pasta enriched with pulse flour, to counteract this low meat intake. Another specific advantage of pulses is that they provide starch with a lower glycemic index than cereal starch. The resistant starch in pulses helps improve glucose tolerance as well as insulin sensitivity, making them a healthy food for people with diabetes or helping prevent the risk of Type 2 diabetes (Mudryj et al., 2014; Laleg et al., 2016).

While pulses' protein supply is strongly promoted, their other nutritional benefits with starch and fiber seem less valued by firms. Business models based on co-product development, such as soy and rapeseed used for both oil and protein, are less advanced for pulses, which can be used for both starch and protein. There is still less scientific knowledge available on the composition, structures, properties, and uses of pulse starches compared to cereals (Hoover et al., 2010). Progress in scientific knowledge is thus required. In addition, some compounds of pulses, include protease inhibitors, phytic acid, and $\alpha$-galactosides, are able to reduce protein digestibility and nutrient absorption and may be responsible for intestinal discomfort. Yet despite these disadvantages, some of these antinutritional factors are now recognized to have beneficial effects on human health (Laleg et al., 2016). For instance, phytic acid has a preventive action against cancer by chelating the metals involved in DNA damage, and $\alpha$-galactosides have some prebiotic activity. Moreover, the amount of bioactive compounds in legumes can be significantly reduced by food processing (soaking, fermentation and germination) and cooking. Hence, we can understand why processing firms recognize that there are many future avenues for the development of pulses in our diets.

Finally, the environmental benefits of pulses are rarely promoted by agrifood firms (for instance, they do not mention environmental benefits on the pulse-based food packaging). However, agrifood firms are beginning to take into account the role pulses can play in fostering sustainable agriculture. Our interviews (Table 1) revealed that firms' first goal is to make pulse products tasty and easier to cook for consumers. Once those objectives are reached, then other arguments to increase pulse consumption may be highlighted depending on consumer trends and public policy discourse about the challenges facing society. Agrifood firms are aware that there are growing numbers of flexitarian and vegetarian consumers (estimated at 30\% flexitarians and 3\% vegetarians among the French population), so most of them are conducting research on plant-protein combinations and assimilation to have more products on the market in the near future.

Thus, advances in nutritional knowledge about pulses may help promote their use, which in turn would support several of the transitions that society is currently facing. However, strong changes in public policy and regulations are still lacking. As regards technology, scientific advances are also needed to encourage the food industry to innovate.

\section{Nutritional and Culinary Education of Consumers About Pulses}

Just as farmers need more knowledge about how to efficiently grow pulses, consumers need to increase their knowledge on the health benefits of eating pulses and how to cook and consume them. "Confidence in cooking, health outcomes, an increase in time devoted to cooking, an enhanced approach toward cooking, and consumption of healthy foods have all been attributed to culinary education" (Havemeier et al., 2017, p. 63). Nutrition education must therefore focus on developing culinary skills, such as food storage, preparation, grocery shopping, and meal planning, rather than only on nutrients. Better knowledge of cooking techniques may help consumers become familiarized with skills that promote the preparation of pulses (Jallinoja et al., 2016; de Boer and Aiking, 2018). As observed in the literature on food nutrition, several researchers included practical advice on how to increase pulse consumption in addition to their results on nutritional effects (see for instance Polak et al., 2015).

Nutrition education on pulses must also include environmental aspects, particularly regarding the challenge of increasing plant-based proteins in diets, as underlined by Hartmann and Siegrist (2017, p. 22): "in order to move toward more sustainable food behavior, consumers and citizens need to have better knowledge about the environmental consequences of their food behavior. Otherwise, it will be unlikely that consumers will be motivated to change their food behavior."

\section{Food Processing Innovations: New Pulse-Based Products}

Agrofood firms in France are currently working to facilitate the consumption of pulses and have already developed new products such as pre-cooked foods combining cereals and pulses. During the last decade, these innovative products have entered the large retail market in most European countries. For instance, we can mention companies such as Tipiak, Sabarot, and Panzani in France, Mopur, Fior di Loto, and Delverde in Italy, and Go Green in Sweden, which have been studied (Lascialfari and Magrini, 2016). Combination products have also been developed by retail brands. For the last several years in the USA, the top global pasta producer, Barilla, has offered pasta made from a mix of pulse and cereal flours on the market. The interviews conducted with these firms confirmed that the main goal behind these new products was to facilitate pulse consumption since pulses suffer from an outdated image. Moreover, the cooking time for lentils ${ }^{5}$, which is the fastest pulse to prepare, is still two to three times longer than that of wheat or rice. While major species such as wheat and rice have benefitted from innovations in varieties and in food processing to reduce their cooking time and to offer new products, such as pre-cooked wheat $\left(\right.$ Ebly ${ }^{\complement}$ brand), little research has been done for pulses.

In France, pasta combining durum wheat flour and large amounts of legume flour has been subject to two studies (PASTALEG and VEGAGE) that showed both the technological feasibility and the specific nutritional qualities of these products.

\footnotetext{
${ }^{5}$ Except for red lentils.
} 
Researchers demonstrated that is possible to make pasta dough with a high percentage (35\%) of pulse flour while using conventional manufacturing processes (Petitot et al., 2010). Another study found that even greater amounts of pulse flour could be used (from 35 to 100\%) with conventional extrusion techniques under adapted conditions, described in an INRA patent $^{6}$ (Laleg et al., 2016, 2017). The resulting pasta is high in protein (and balanced in essential amino acids) for the mixed legume-cereal product, gluten-free for the $100 \%$ legume pasta, and high in fiber, vitamin $\mathrm{B} 1, \mathrm{Mg}$, and $\mathrm{P}$. The pasta is also low in fat and in the alpha-galactosides responsible for flatulence. For the moment, none of these new mixed pastas is available in significant quantities on the French market. Current French regulations define pasta as made exclusively from durum wheat, meaning that these products cannot be labeled as "pasta" (only sold as a health-food product but not as common food product). This example thus shows one of the ways in which institutions condition firms' market strategy.

\section{Food Processing: The Development of Protein Ingredients}

Pulse processing technologies have particularly evolved in recent years, even though the applications are still mainly oriented toward animal feed. Today, the market for pulses as ingredients in the French food industry (high-processing technologies) is increasing and estimated at 120,000 metric tons/year ${ }^{7}$, mostly for protein-rich peas (over 80,000 metric tons/year). In comparison, the market for direct consumption of pulses (mainly lentils, beans, and chickpeas) is estimated at 100,000 metric tons/year (more half of which is imported in France). Over half is processed with simple technologies (flours or canned products), while the remainder is sold as whole pulses for cooking. Thus, the market for food ingredients (high-processing technologies) has surpassed traditional consumption. This development is largely due to the progress of nutritional knowledge (see above) and the recognition of other functional properties, all of which contribute to transitioning the practices of food-processing industries. Many experts recognize there is still great potential for innovation due to technology transfers among sub-sectors of the food industry.

Ingredients derived from protein-rich plants are currently driving a dynamic worldwide market (Guéguen et al., 2016). Several technological processes provide these ingredients in various forms (flours, concentrates, isolates, etc.), which are characterized by different protein contents in dry matter (from $45 \%$ to over $90 \%$ ). These ingredients are then incorporated into food products for their technological and nutritional properties. In France, two food product categories account for two-thirds of the foods containing vegetable proteins: bread/pastry and meat products (protein from pulses is added into meat preparations). In addition to their economic advantages, these plant proteins have features that optimize the texture and/or physical stability of the products by controlling rheological, emulsifying, foaming, and water retention properties. Some of their texturing properties (emulsions, foams, gels) mean they can substitute for other

\footnotetext{
${ }^{6}$ Patent FR 1462811 -WO2016097328A1.

${ }^{7}$ Data from industry organizations.
}

materials (in particular for milk products). For instance, in the pastry sector, some manufacturers have replaced eggs with lupine flour, which have emulsifying properties, in addition to a yellow color and a high protein content. In another example, fava bean flour in bread enables a lighter color of the bread crumb. Today, most of these uses are limited to niche markets, but their use is expanding and these innovations should increase the demand for pulses.

However, some uses of these plant protein extracts are still hampered by lower functional performance compared with certain animal proteins (milk protein, egg products, gelatin) and by limited consumer acceptability because of an oftenpronounced "plant" taste (or "green" taste). Progress must be made to overcome these sensory bottlenecks and to increase protein solubility (Chardigny and Walrand, 2016). Considering the achievements in recent decades, several avenues are worth exploring: (i) better managing the diversity of legume proteins' functional potential; (ii) reducing undesirable tastes; and (iii) improving functional synergies between plant and animal proteins and other biopolymers (starch or other polysaccharides).

Highly innovative approaches, such as combining different plant proteins (pulses/cereals) or animal/vegetable proteins for better functionality, are currently being developed in many laboratories in both the public and private sectors. However, according to those researchers, to consolidate these new outlets for pulses, more research and development are required to (i) improve the extraction and recovery of co-products; (ii) screen functional assemblies for their innovative properties and the ease of obtaining them compared to purified molecules; (iii) develop animal/plant protein mixes for common products (incorporate plant proteins with animal proteins in formulated products that usually only contain animal protein such as cheese, yogurt) to spread the use of plant proteins and promote learning about their industrial uses; and (iv) update processes to incorporate eco-design, as the specificities of plant proteins (ability to aggregate, low solubility, interactions with metals, etc.) should lead us to rethink manufacturing processes. Firms also state that research on the latter should focus on methods that are environmentally beneficial, through greater production efficiency in transformation processes. In the same spirit, hydrolysis treatments improving solubility or fermentation, as well as innovative physical treatments (high pressure, microwaves, etc.) for texturing, are other technological advantages to consider. These various avenues to be explored create new market opportunities with high added value because they are based on specific technological advances for which few countries in the world have the required know-how. However, this should not deter us from making direct consumption of whole pulses more attractive to consumers; products should also be developed for diversifying the consumption of whole or minimally processed pulses.

All these types of outlets based on various processing pathways (for proteins, carbohydrates, fibers, starch, etc.) should be considered as innovation niches that can become dynamic markets in the future (Chéreau et al., 2016). But for the moment, this development calls for strong public investment in research to overcome lock-in. Indeed public research on pulses 
is under-financed compared to major crops and soy, especially in food sciences (Sonnino, 2017). If we look at the position of grain-legume species in current food sciences, soy is currently the most researched crop (Figure 4) and strongly linked to protein research, whereas pea, fava bean and lupin are studied much less.

\section{Coupling Upstream and Downstream Innovations}

Whatever the technological process chosen to develop pulses, these innovations alone will not be sufficient to un-lock the entire agrifood system if upstream production is not simultaneously improved and developed. For example, new product innovations could trigger the breeding of new varieties adapted to food processing needs. Then, crop production must also increase to supply these new markets. As the processing firm Roquette (a major European food processor of pea protein) explained, they decided to focus their investment on pea protein in Canada rather than Europe, since Canadian pea production is greatly increasing. Barilla faces the same dilemma, as they are waiting for a greater institutional commitment from Europe to supply pulses. Other food processing firms such as Cosucra have tried to sign crop contracts with farmers to increase pulse production. It is clear that organizational innovations are also required to foster upstream and downstream changes. However, contractual arrangements in the pulse sector are still in the emerging phase, attempting to strengthen coordination among the supply chain stakeholders (Cholez et al., 2017). All stakeholders need to be involved in designing interconnected innovations, which opens up many avenues for future research as suggested by Meynard et al. (2016). Forums that bring together multiple types of stakeholders working toward an agro ecological transition, as suggested by Le Masson et al. (2012), would also be useful, especially in order to share a common diagnosis of food system perspectives (Meynard et al., 2016).

\section{CONCLUSION}

Breaking agricultural and food systems (i.e., the agrifood system) out of lock-in requires new increasing returns to adoption that foster crop and food alternatives such as pulses. This article has explored various innovation paths regarding pulses, both upstream and downstream of supply chains, to get insights on the alignments that are possible. We have considered this alignment as the condition needed to trigger a sustainable agrifood transition in favor of pulses. In this article, we have stressed the importance of a co-evolution involving technologies, ecosystem, institutions, private actors, and research, in order to understand how innovations in one area can trigger changes in another.

The main conclusion is that public institutions have a major role in supporting this transition because the simultaneous evolution of the downstream and the upstream of the system is complex. In particular, public institutions need to: support investment in new storage facilities upstream and new processing technologies downstream; foster the sharing of information and knowledge on innovative cropping systems that include pulses (especially in agricultural advising) upstream, and the benefits of consuming pulses downstream. That is, to successfully accomplish the agrifood transition on pulses, policy makers need to view agricultural, and food policies as strongly interconnected.

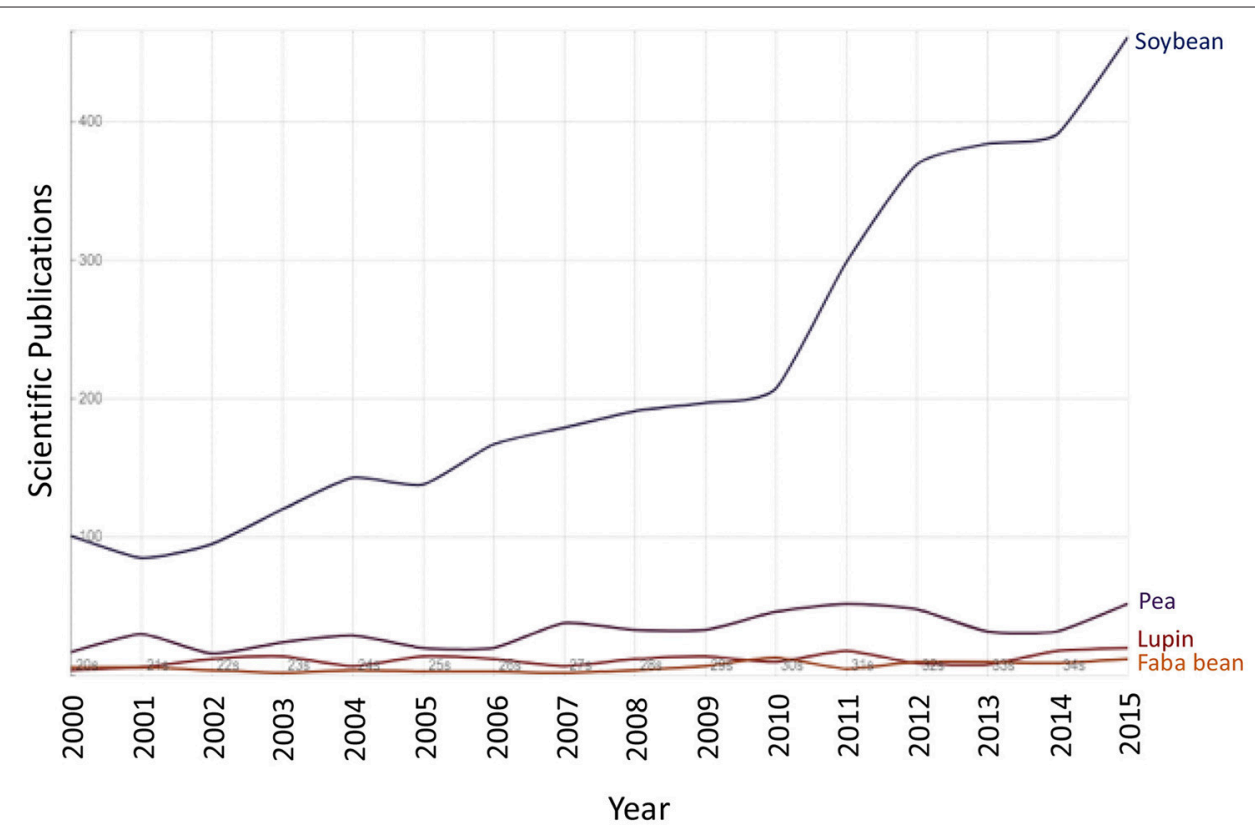

FIGURE 4 | Scientific publications on soybean, pea, fava, and lupin in food sciences, published between 2000 and 2015 and registered on the Web of Science (WoS, Clarivate Analytics) This graph has been created by the authors based on specific search queries of various key words for the main topics of food science (excluding oil use), restricted to those species. The search query was done on titles, abstracts, and key words among the articles registered on the Web of Science (WoS, Clarivate Analytics) between 2000 and 2015. These results come from a larger bibliometric study in progress by the authors. The search query is available on request. 


\section{AUTHOR CONTRIBUTIONS}

M-BM contributed conception and design of the paper, and wrote the first draft of the manuscript. All the other authors wrote several contributions in different sections of the manuscript. All authors contributed to manuscript revision, read and approved the submitted version.

\section{FUNDING}

Funding support for this article was provided by: the French National Research Agency (ANR) as part of the ANR-13-AGRO-0004 project LEGITIMES (LEGume

\section{REFERENCES}

Allaire, G. (2010). Applying economic sociology to understand the meaning of "Quality" in food markets. Agric. Econ. 41, 167-180. doi: $10.1111 / j .1574-0862.2010 .00498 . x$

Altieri, M. (1999). The ecological role of biodiversity in agroecosystems. Agric. Ecosyst. Environ. 74, 19-31. doi: 10.1016/S0167-8809(99)00028-6

Anglade, J., Billen, G., and Garnier, J. (2015). Relationships for estimating N2 fixation in legumes: incidence for $\mathrm{N}$ balance of legume-based cropping systems in Europe. Ecosphere 6, 1-24. doi: 10.1890/ES14-00353.1

Arthur, B. (1989). Competing technologies, increasing returns, and lock-in by historical events. Econ. J. 99, 116-131. doi: 10.2307/2234208

Arthur, W. B. (1994). Increasing Returns and Path Dependence in the Economy. University of Michigan Press.

Auestad, N., and Fulgoni, V. L. III. (2015). What current literature tells us about sustainable diets : emerging research linking dietary patterns, environmental. Adv. Nutr. 6, 19-36. doi: 10.3945/an.114.005694

Bedoussac, L., Journet, E. P., Hauggaard-Nielsen, H., Naudin, C., Corre-Hellou, G., Jensen, E. S., et al. (2015). Ecological principles underlying the increase of productivity achieved by cereal-grain legume intercrops in organic farming. A review. Agron. Sustain. Dev. 35, 911-935. doi: 10.1007/s13593-014-0277-7

Benett, A. J., Bending, G. D., Chandler, D., Hilton, S., and Mills, P. (2012). Meeting the demand for crop production: the challenge of yield decline in crops grown in short rotations. Biol. Rev. 87, 52-71. doi: 10.1111/j.1469-185X.2011.00184.x

Cernay, C., Makowski, D., and Pelzer, E. (2018). Preceding cultivation of grain legumes increases cereal yields under low nitrogen input conditions. Environ. Chem. Lett. 16, 631-636. doi: 10.1007/s10311-017-0698-z

Champ, M., Magrini, M. B., Simon, N., and Le Guillou, C. (2015). "Les légumineuses pour l'alimentation humaine: conséquences nutritionnelles et effets santé, usages et perspectives," in Les LégumineusesDans les Systèmes de Production Agricole - Etat des Connaissances et ImpactsAgronomiques, Environnementaux et Économiques, eds A. Schneider and C. Huyghe (Paris: Editions QUAE).

Chardigny, J. M., and Walrand, S. (2016). Plant protein for food: opportunities and bottlenecks. OCL 23:D404. doi: 10.1051/ocl/2016019

Chéreau, D., Videcoq, P., Ruffieux, C., Pichon, L., Motte, J. C., Belaid, S., et al. (2016). Combination of existing and alternative technologies to promote oilseeds and pulses proteins in food applications. OCL 23:D406. doi: $10.1051 / \mathrm{ocl} / 2016020$

Chhetri, N. B., Easterling, W. E., Terando, A., and Mearns, L. (2010). Modeling path dependence in agri- cultural adaptation to climate variability and change. Ann. Assoc. Am. Geogr. 100, 894-907. doi: 10.1080/00045608.2010.500547

Cholez, C., Magrini, M.-B., and Galliano, D. (2017). "Contrats de production en grandes cultures: incitations et coordination en contexte d'incertitude technique," in Journées de la SFER (Nancy).

Clonan, A., Wilson, P., Swift, J. A., Leibovici, D. G., and Holdsworth, M. (2015). Red and processed meat consumption and purchasing behaviours and attitudes: impacts for human health, animal welfare and environmental
Insertion in Territories to Induce Main Ecosystem Services); the European Union's Horizon 2020 research and innovation program under grant agreement No 727672-LEGVALUE (Fostering sustainable legume-based farming systems and agri-feed and food chains in the EU); INRA [the French National Institute for Agricultural Research].

\section{ACKNOWLEDGMENTS}

This article was translated by Cynthia J. Johnson. We also thank the reviewers whose comments and suggestions helped sharpen the argument. sustainability. Public Health Nutr. 18, e2446-e2456. doi: 10.1017/S13689800150 00567

Combris, P., Goglia, R., Henini, M., Soler, L. G., and Spiteri, M. (2011). Improvement of the nutritional quality of foods as a public health tool. Public Health 125, 717-724. doi: 10.1016/j.puhe.2011.07.004

Cowan, R., and Gunby, P. (1996). Sprayed to death: path dependence, lock-in and pest control strategies. Econ. J. 106, 521-542. doi: 10.2307/2235561

Curran, J. (2012). The nutritional value and health benefits of pulses in relation to obesity, diabetes, heart disease and cancer. Br. J. Nutr. 108, S1-S2. doi: 10.1017/S0007114512003534

Dahl, W. J., Foster, L. M., and Tyler, R. T. (2012). Review of the health benefits of peas (Pisum sativum L.). Br. J. Nutr. 108, S3-S10. doi: $10.1017 /$ S0007114512000852

de Boer, J., and Aiking, H. (2018). Prospects for pro-environmental protein consumption in Europe: cultural, culinary, economic and psychological factors. Appetite 121, 29-40. doi: 10.1016/j.appet.2017.10.042

Ebert, A. W. (2014). Potential of underutilized traditional vegetables and legume crops to contribute to food and nutritional security, income and more sustainable production systems. Sustainability 6, 319-335. doi: $10.3390 /$ su6010319

Elzen, B., and Barbier, M. (2012). System Innovations, Knowledge Regimes, and Design Pactices towards Transitions for Sustainable Agriculture. ThivervalGrignon: INRA Editions.

Elzen, B., Geels, F. W., Leeuwis, C., and van Mierlo, B. (2011). Normative contestation in transitions 'in the making': animal welfare concerns and system innovation in pig husbandry. Res. Policy 40, 263-275. doi: 10.1016/J.RESPOL.2010.09.018

Eurostat (2016). Dry Pulses in EU Agriculture - Statistics on Cultivation, Production and Economic Value. Available online at: http://ec.europa.eu/eurostat/statisticsexplained/pdfscache/54636.pdf (Accessed January 20, 2017).

Foxon, T. J. (2011). A coevolutionary framework for analysing a transition to a sustainable low carbon economy. Ecol. Econ. 70, 2258-2267. doi: 10.1016/j.ecolecon.2011.07.014

Foxon, T. J., Köhler, J., Michie, J., and Oughton, C. (2013). Towards a new complexity economics for sustainability. Cambridge J. Econ. 37, 187-208. doi: 10.1093/cje/bes057

Francis, C., Lieblein, G., Gliessman, S., Breland, T. A., Creamer, N., Harwood, R., et al. (2003). Agroecology: the ecology of food systems. J. Sustain. Agric. 22, 99-118. doi: 10.1300/J064v22n03_10

Friel, S., Dangour, A. D., Garnett, T., Lock, K., Chalabi, Z., Roberts, I., et al. (2009). Public health benefits of strategies to reduce greenhouse-gas emissions: food and agriculture. Lancet 374, 2016-2025. doi: 10.1016/S0140-6736(09)61753-0

Garnett, T. (2013). Food sustainability: problems, perspectives and solutions. Proc. Nutr. Soc. 72, 29-39. doi: 10.1017/S0029665112002947

Geels, F. W. (2004). From sectoral systems of innovation to socio-technical systems: insights about dynamics and change from sociology and institutional theory. Res. Policy 33, 897-920. doi: 10.1016/j.respol.2004. 01.015 
GEPV (2016). Protéines Végétales, des Ingrédients de Plus en Plus Connus, Lettre Positions $n^{\circ} 61$. Available online at: http://www.gepv.asso.fr/Default.aspx?lid= 7\&rid $=617$ \&rvid $=635$

Gogoi, N., Baruah, K. K., and Meena, R. S. (2018). "Grain legumes: impact on soil health and agroecosystem," in Legumes for Soil Health and Sustainable Management (Singapore: Springer), 511-539.

González, A. D., Frostell, B., and Carlsson-Kanyama, A. (2011). Protein efficiency per unit energy and per unit greenhouse gas emissions: potential contribution of diet choices to climate change mitigation. Food Policy 36, 562-570. doi: 10.1016/j.foodpol.2011.07.003

Grassini, P., Eskridge, K. M., and Cassman, K. G. (2013). Distinguishing between yield advances and yield plateaus in historical crop production trends. Nat. Commun. 4:2918. doi: 10.1038/ncomms3918

Guéguen, J., Walrand, S., and Bourgeois, O. (2016). Les protéines végétales: contexte et potentiels en alimentation humaine. Cahiers Nutr. Diét. 51, 177-185. doi: 10.1016/j.cnd.2016.02.001

Hallström, E., Carlsson-Kanyama, A., and Börjesson, P. (2015). Environmental impact of dietary change: a systematic review. J. Clean. Prod. 91, 1-11. doi: 10.1016/j.jclepro.2014.12.008

Hartmann, C., and Siegrist, M. (2017). Consumer perception and behavior regarding sustainable protein consumption: a systematic review. Trends Food Sci. Technol. 61, 11-25. doi: 10.1016/j.tifs.2016.12.006

Havemeier, S., Erickson, J., and Slavin, J. (2017). Dietary guidance for pulses: the challenge and opportunity to be part of both the vegetable and protein food groups. Ann. N. Y. Acad. Sci. 1392, 58-66. doi: 10.1111/nyas.13308

Henchion, M., Hayes, M., Mullen, A. M., Fenelon, M., and Tiwari, B. (2017). Future protein supply and demand: strategies and factors influencing a sustainable equilibrium. Foods 6:E53. doi: 10.3390/foods6070053

Hoover, R., Hughes, T., Chung, H. J., and Liu, Q. (2010). Composition, molecular structure, properties, and modification of pulse starches: a review. Food Res. Int. 43, 399-413.doi: 10.1016/j.foodres.2009.09.001

Horlings, L. G., and Marsden, T. K. (2011). Towards the real green revolution? Exploring the conceptual dimensions of a new ecological modernisation of agriculture that could 'feed the world'. Glob. Environ. Change 21, 441-452. doi: 10.1016/j.gloenvcha.2011.01.004

IPES-Food (2017). Unravelling the Food-Health Nexus: Addressing Practices, Political Economy, and Power Relations to Build Healthier Food Systems. The Global Alliance for the Future of Food and IPES-Food. Available online at: http:// www.ipes-food.org/images/Reports/Health_FullReport.pdf (Accessed January 19, 2018)

Jahn, J. L., Stampfer, M. J., and Willett, W. C. (2015). Food, health \& the environment: a global grand challenge \& some solutions. Daedalus 144, 31-44. doi: 10.1162/DAED_a_00352

Jallinoja, P. T., Niva, M. H., and Latvala, T. T. (2016). Future of sustainable eating? Futures 83, 4-14. doi: 10.1016/j.futures.2016.03.006

Jensen, E., Peoples, M., Boddey, R., Gresshoff, P., Hauggaard-Nielsen, H., Alves, B. J. R., et al. (2012) Legumes for mitigation of climate change and the provision of feedstock for biofuels and biorefineries. A review. Sustain. Dev. 32, 329-364. doi: 10.1007/s13593-011-0056-7

Kemp, R., Schot, J., and Hoogma, R. (1998). Regime shifts to sustainability through processes of niche formation: the approach of strategic niche management. Tech. Anal. Strat. Manage. 10, 175-198. doi: 10.1080/09537329808 524310

Kuhlman, T., Helming, J., and Linderhof, V. (2017). Optimizing legume cropping: the policy questions. Legumes Crop. Syst. 16, 226-243.

Kuokkanen, A., Mikkilä, M., Kuisma, M., Kahiluoto, H., and Linnanen, L. (2016). The need for policy to address the food system lock-in: a case study of the Finnish context. J. Cleaner Prod. 140, 933-944. doi: 10.1016/j.jclepro.2016.06.171

Laleg, K., Barron, C., Cordelle, S., Schlich, P., Walrand, S., and Micard, V. (2017). How structure, nutritional and sensory attributes of pasta made from legume is impacted by the legume protein. Food Sci. Tech. 49, 471-478. doi: 10.1016/j.lwt.2017.01.069

Laleg, K., Barron, C., Santé-Lhoutellier, V., Walrand, S., and Micard, V. (2016). Protein enriched pasta: structure and digestibility of its protein network. Food Funct. 7, 1196-1207. doi: 10.1039/c5fo01231g

Lang, T., and Barling, D. (2013). Nutrition and sustainability: an emerging food policy discourse. Proc. Nutr. Soc. 72, 1-12. doi: 10.1017/S002966511200290X
Laperche, B. (2012). General presentation innovation processes: why institutions matter? J. Innov. Econ. Manage. 9, 232-233. doi: 10.3917/jie.009.0003

Lascialfari, M., and Magrini, M. B. (2016). "Towards more sustainable diets: insights from firms' innovation dynamics on new legumes-based food products," in Journées de Recherches en Sciences Sociales (Paris).

Lassaletta, L., Billen, G., Grizzetti, B., Garnier, J., Leach, A. M., and Galloway, J. N. (2014). Food and feed trade as a driver in the global nitrogen cycle: 50-year trends. Biogeochemistry 118, 225-241. doi: 10.1007/s10533-013-9923-4

Le Masson, P., Weil, B., Hatchuel, A., and Cogez, P. (2012). Why aren't they locked in waiting games? Unlocking rules and the ecology of concepts in the semiconductor industry. Tech. Anal. Strat. Manage. 24, 617-630. doi: 10.1080/09537325.2012.693675

Loyce, C., Meynard, J. M., Bouchard, C., Rolland, B., Lonnet, P., Bataillon, P., et al. (2012). Growing winter wheat cultivars under different management intensities in France: a multicriteria assessment based on economic, energetic and environmental indicators. Field Crop Res. 125, 167-178. doi: 10.1016/j.fcr.2011.08.007

Magrini, M.-B., Anton, M., Cholez, C., Corre-Hellou, G., Duc, G., Jeuffroy, M.-H., et al. (2016). Why are grain-pulses rarely present in cropping systems despite their environmental and nutritional benefits? Analyzing lock-in in the French agrifood system. Ecol. Econ. 126, 152-162. doi: 10.1016/j.ecolecon.2016.03.024

Magrini, M. B., Triboulet, P., and Bedoussac, L. (2013). Pratiques agricoles innovantes et logistique des coopératives agricoles. Une étude ex-ante sur l'acceptabilité de cultures associées blé dur-légumineuses. Economie Rurale 38, 25-45. Available online at: https://journals.openedition.org/economierurale/ 4145

Mahmood, F., Belhouchette, H., Nasim, W., Shahzad, T., Hussain, S., Therond, O., et al. (2017). Economic and environmental impacts of introducing grain legumes in farming systems of midi-Pyrénées region (France): a simulation approach. Int. J. Plant Prod. 11, 65-87.

Markard, J., Raven, R., and Truffer, B. (2012). Sustainability transitions: an emerging field of research and its prospects. Res. Policy 41, 955-967. doi: 10.1016/j.respol.2012.02.013

Marlow, H. J., Harwatt, H., Soret, S., and Sabaté, J. (2015). Comparing the water, energy, pesticide and fertilizer usage for the production of foods consumed by different dietary types in California. Public Health Nutr. 18, 2425-2432. doi: $10.1017 /$ S1368980014002833

Marsden, T. (2012). Towards a real sustainable agri-food security and food policy: beyond the ecological fallacies? Polit. Q. 83, 139-145. doi: 10.1111/j.1467-923X.2012.02242.x

Meynard, J. M., Jeuffroy, M. H., Le Bail, M., Lefèvre, A., Magrini, M. B., and Michon, C. (2016).Designing coupled innovations for the sustainability transition of agrifood systems. Agric. Syst. 157, 330-339. doi: 10.1016/j.agsy.2016.08.002

Meynard, J. M. Messéan, A., Charlier, A., Charrier, F., Fares, M., Le Bail, M. B., et al. (2013). Crop Diversification: Obstacles and Levers. Study of Farms and Supply Chains., Synopsis of the Study Carried out by INRA at the Request of the Ministries in Charge of Agriculture and Ecology. INRA. Available online at: https://www6.paris.inra.fr/depe/Media/Fichier/Etudes/Diversification-descultures/synthese-anglais

Mudryj, A. N., Yu, N., and Aukema, H. M. (2014). Nutritional and health benefits of pulses. Appl. Physiol. Nutr. Metab. 39, 1197-1204. doi: 10.1139/apnm-2013-0557

Murphy-Bokern, D., Stoddard, F. L., and Watson, C. A. (2017). Legumes in Cropping Systems. CABI. Available online at: https://www.cabi.org/cabebooks/ ebook/20173152105

Ndzana, R. A., Magro, A., Bedoussac, L., Justes, E., Journet, E.-P., and Hemptinne, J.-L. (2014). Is there an associational resistance of winter pea-durum wheat intercrops towards Acyrthosiphon pisum Harris? J. Appl. Entomol. 138, 577-585. doi: 10.1111/jen.12119

Nemecek, T., Hayer, F., Bonnin, E., Carrouée, B., Schneider, A., and Vivier, C. (2015). Designing eco-efficient crop rotations using life cycle assessment of crop combinations. Eur. J. Agron. 65, 40-51. doi: 10.1016/j.eja.2015. 01.005

Nguyen, G., Mawois, M., and Casagrande, M. (2016). Etude des Freins et Leviers à linsertion des Légumineuses Dans Trois Territoires Contrastés (Bourgogne, Midi-Pyrénées, Pays de la Loire). Premières Rencontres Francophones des Légumineuses, les 31 mai et 1er juin 2016, Dijon. Available online at: https:// 
www.b2match.eu/system/rencontres-francophones-legumineuses/files/32. MAWOIS_Marie.pdf?1470410740 (Accessed September 15, 2016).

Nijdam, D., Rood, T., and Westhoek, H. (2012). The price of protein: review of land use and carbon footprints from life cycle assessments of animal food products and their substitutes. Food Policy 37, 760-770. doi: 10.1016/j.foodpol.2012.08.002

North, D. C. (2003). Understanding Processes of Economic Change. Cambridge University Press.

OECD-FAO (2013). Agricultural Outlook 2013-2022. Available online at: http:// www.oecd.org/site/oecd-faoagriculturaloutlook/publication.htm

Pelzer, E., Bazot, M., Makowski, D., Corre-Hellou, G., Naudin, C., Al Rifaï, M., et al. (2012) Pea-wheat intercrops in low-input conditions combine high economic performances and low environmental impacts. Eur. J. Agron. 40, 39-53. doi: 10.1016/j.eja.2012.01.010

Petitot, M., Abecassis, J., and Micard, V. (2009). Structuring of pasta components during processing: impact on starch and protein digestibility and allergenicity. Trends Food Sci. Technol. 20, 521-532. doi: 10.1016/j.tifs.2009.06.005

Petitot, M., Boyer, L., Minier, C., and Micard, V. (2010). Fortification of pasta with split pea and fava bean flours: pasta processing and quality evaluation. Food Res. Int. 43, 634-641. doi: 10.1016/j.foodres.2009.07.020

Polak, R., Phillips E., and Campbell, A. (2015). Clinical diabetes: a publication of the American Diabetes Association. Am. Diabetes Assoc. 33, 198-205. doi: $10.2337 / \mathrm{cd} 17-0099$

Ranganathan, J., Vennard, D., Waite, R., Lipinski, B., Searchinger, T., Dumas, P., et al. (2016). "Shifting diets for a sustainable food future," in Working Paper, Installment 11 of Creating a Sustainable Food Future. Washington, DC:World Resources Institute. Available online at: http://www.worldresourcesreport.org

Ravier, C., Jeuffroy, M.-H., Gate, P., Cohan, J.-P., Meynard, J.-M. (2018). Combining diagnosis of uses with participatory design to develop new methods for managing wheat N fertilization. Nutr. Cycl. Agroecosyst. 110, 117-134. doi: 10.1007/s10705-017-9891-5

Reckling, M., Hecker, J. M., Bergkvist, G., Watson, C. A., Zander, P., Schläfke, N., et al. (2016). A cropping system assessment framework-evaluating effects of introducing legumes into crop rotations. Eur. J. Agron. 76, 186-197. doi: 10.1016/j.eja.2015.11.005

Rennings, K. (2000). Redefining innovation - eco-innovation and the contribution from ecological economics. Ecol. Econ. 32, 319-332. doi: 10.1016/S0921-8009(99)00112-3

Scarborough, P., Appleby, P. N., Mizdrak, A., Briggs, A. D., Travis, R. C., Bradbury, K. E., et al. (2014). Dietary greenhouse gas emissions of meat-eaters, fish-eaters, vegetarians and vegans in the UK. Clim. Change 125, 179-192. doi: 10.1007/s10584-014-1169-1

Schneider, A., and Huyghe, C. (eds). (2015). Les légumineuses Pour des Systèmes Agricoles et Alimentaires Durables. QUAE Editions, 473.

Sirtori, C. R., Triolo, M., Bosisio, R., Bondioli, A., Calabresi, L., De Vergori, V., et al. (2012). Hypocholesterolaemic effects of lupin protein and pea protein/fibre combinations in moderately hypercholesterolaemic individuals. Br. J. Nutr. 107, 1176-1183. doi: 10.1017/S0007114511004120

Sonnino, A. (2017). Leguminose da Granella e Ricerca Agricola - Pulses and Agricultural Research. Atti del Seminario Leguminose da Granella Sant'Angelo Lodigiano, 14 Ottobre 2016, 45-50. Available online at: https:// sites.google.com/site/storiagricoltura/download-area/atti_seminari_mulsa (Accessed July 5, 2018).

Stoate, C., Báldi, A., Beja, P., Boatman, N. D., Herzon, I., Van Doorn, A., et al. (2009). Ecological impacts of early 21 st century agricultural change in Europe-a review. J. Environ. Manage. 91, 22-46. doi: 10.1016/j.jenvman.2009.07.005

Therond, O., Duru, M., Roger-Estrade, J., and Richard, G. (2017). A new analytical framework of farming system and agriculture model diversities. A review. Agron. Sustain. Dev. 37:21. doi: 10.1007/s13593-017-0429-7

Tilman, D., and Clark, M. (2014). Global diets link environmental sustainability and human health. Nature 515, 518-522. doi: 10.1038/nature13959

Tilman, D., and Clark, M. (2015). Food, agriculture and the environment: can we feed the world and save the Earth? Daedalus 144, 8-23. doi: 10.1162/DAED_a_00350
Toffolini, Q., Jeuffroy, M.-H., Mischler, P., Pernel, J., and Prost, L. (2016). Farmers' use of fundamental knowledge to re-design their cropping systems: situated contextualisation processes. NJAS 80, 37-47. doi: 10.1016/j.njas.2016.11.004

Tome, D. (2012). Criteria and markers for protein quality assessment - a review. Br. J. Nutr. 108, S222-S229. doi: 10.1017/S000711451 2002565

Touzard, J. M., Temple, L., Faure, G., and Triomphe, B. (2015). Innovation systems and knowledge communities in the agriculture and agrifood sector: a literature review. J. Innov. Econ. Manage. 2, 117-142. doi: 10.3917/jie.017.0117

Vanloqueren, G., and Baret, P. V. (2008). Why are ecological, lowinput, multi-resistant wheat cultivars slow to develop commercially? A Belgian agricultural 'lock-in' case study. Ecol. Econ. 66, 436-446. doi: 10.1016/j.ecolecon.2007.10.007

Vanloqueren, G., and Baret, P. V. (2009). How agricultural research systems shape a technological regime that develops genetic engineering but locks out agroecological innovations. Res. Policy 38, 971-983. doi: 10.1016/j.respol.2009.02.008

Vasseur, C., Joannon, A., Aviron, S., Burel, F., Meynard, J. M., and Baudry, J. (2013). The cropping systems mosaic: how does the hidden heterogeneity of agricultural landscapes drive arthropod populations? Agric. Ecosyst. Environ. 166, 3-14. doi: 10.1016/j.agee.2012.08.013

Voisin, A. S., Guéguen, J., Huyghe, C., Jeuffroy, M. H., Magrini, M. B., Meynard, J. M., et al. (2014). Legumes for feed, food, biomaterials and bioenergy in Europe: a review. Agron. Sustain. Dev. 343, 361-380. doi: 10.1007/s13593-013-0189-y

Watson, C. A., Reckling, M., Preissel, S., Bachinger, J., Bergkvist, G., Kuhlman, T., et al. (2017). Grain legume production and use in european agricultural systems. Adv. Agron. 144, 235-303. doi: 10.1016/bs.agron.2017.03.003

Weiner, J. (2017). Applying plant ecological knowledge to increase agricultural sustainability. J. Ecol. 105, 865-870. doi: 10.1111/1365-2745.12792

Westhoek, H., Lesschen, J. P., Rood, T., Wagner, S., De Marco, A., MurphyBokern, D., et al. (2014). Food choices, health and environment: effects of cutting Europe's meat and dairy intake. Glob. Environ. Change 26, 196-205. doi: 10.1016/j.gloenvcha.2014.02.004

Wezel, A., Casagrande, M., Celette, F., Vian, J. F., Ferrer, A., and Peigné, J. (2014). Agroecological practices for sustainable agriculture. A review. Agron. Sustain. Dev. 34, 1-20. doi: 10.1007/s13593-013-0180-7

Whitmee, S., Haines, A., Beyrer, C., Boltz, F., Capon, A. G., de Souza Dias, B. F., et al. (2015). Safeguarding human health in the Anthropocene epoch: report of The Rockefeller Foundation-Lancet Commission on planetary health. Lancet 386, 1973-2028. doi: 10.1016/S0140-6736(15)60901-1

Wilson, C., and Tisdell, C. (2001). Why farmers continue to use pesticides despite environmental, health and sustainability costs. Ecol. Econ. 39, 449-462. doi: 10.1016/S0921-8009(01)00238-5

Wolff, H., and Recke, G. (2000). Path dependence and implementation strategies for integrated pest management. Q. J. Int. Agric. 39, 149-172.

Zander, P., Amjath-Babu, T. S., Preissel, S., Reckling, M., Bues, A., Schläfke, N., et al. (2016). Grain legume decline and potential recovery in European agriculture: a review. Agron. Sustain. Dev. 36:26. doi: 10.1007/s13593-016-0365-y

Zimmer, S., Liebe, U., Didier, J. P., and Heß, J. (2016). Luxembourgish farmers' lack of information about grain legume cultivation. Agron. Sustain. Dev. 36, 1-10. doi: 10.1007/s13593-015-0339-5

Conflict of Interest Statement: The authors declare that the research was conducted in the absence of any commercial or financial relationships that could be construed as a potential conflict of interest.

Copyright (c) 2018 Magrini, Anton, Chardigny, Duc, Duru, Jeuffroy, Meynard, Micard and Walrand. This is an open-access article distributed under the terms of the Creative Commons Attribution License (CC BY). The use, distribution or reproduction in other forums is permitted, provided the original author(s) and the copyright owner(s) are credited and that the original publication in this journal is cited, in accordance with accepted academic practice. No use, distribution or reproduction is permitted which does not comply with these terms. 


\section{APPENDIX}

\section{Summary of the Interview Guide With Agrofood Companies That Have Launched a new Pulse-Based Food Product}

\section{Starting Question:}

Could you tell us how and why your enterprise decided to launch this new product based on pulses?

\section{Concerning Your Business Strategy on Consumers, Could you Give us More Details:}

- What are the determinants of consumers' purchase and acceptance?

- Is it a "pure" novelty for the market? Did you get inspiration from a niche product or a small firm?

- What is the influence of food trends? Who is the targeted consumer?

- Do you promote specific nutritional aspects?

- Do you promote specific environmental benefits?

- Is it a meat-substitute?

- Is it sold at a premium price? Comparing to which other products?

- What were the sales after the launch? Have they been growing or decreasing?

- Did competitors imitate your product?

- What obstacles did you encounter when launching your product into the market?

- Did you develop other similar foodstuffs? Have you had any failures with other food product innovations?

Concerning the Food Processing Technologies Used:

- Did you file a patent for your product?

- How did you design the pulse processing?

- Do you directly process your product? Did you need to adapt your production chain? If not, which processed pulses do you buy? With a specific parternship?

- Which kind of texture, color and tasting properties did you work on? What is the importance of cooking time?

\section{Concerning the Knowledge Required to Develop Your Innovation, Could you Explain:}

- Tthe nutritional aims in product development? Did you work on the amino-acid balance and limitations? Or on other nutritional factors? Did you take into account anti-nutritional factors or allergies related to pulses?

- Did you work with an external organization (R\&S firm, academic, etc.) to develop your product?

\section{Concerning Your Links With Agricultural Production:}

- What is the geographical origin of the raw materials used, especially pulses?

- Do you use production contracts?

- What kind of pulses did you use? Were there specific quality specifications? If so, why?

- Is the increase of pulse cultivation in Europe part of your strategy?

- Do you have direct relations with farmers? Do you establish agreements to adopt pulses for crop rotations in order to obtain more sustainable wheat?

- What would you ask for from scientific research, in order to promote pulse development?

\section{Concerning the Downstream of the Supply Chain:}

- Were supply and marketing chains determinant for the choice of markets?

- Did you encounter differences between marketing chains in different countries?

- In which supermarkets did you place your products?

- In which main product lines are your products positioned? For instance, as a product for vegetarians or those with specific dietary requirements? Or among "standard" pasta and rice products?

Regarding the Institutional and Political Environment:

- Did you get support from public institutions in the development and launch of your product? which institutions Did you work with? Did you lobby them? How do you judge cooperation with public agencies, comparatively between European and North American ones?

- Is current legislation an obstacle for your product? Would you like to see a change in European legislation on pulses?

- How do you judge the implementation of nutritional objectives accross various countries?

- What are the main policy challenges for developing pulses in your country and/or Europe? 